\title{
Effects of a snowstorm event on the interactions between plants and hummingbirds: fast recovery of spatio-temporal patterns
}

\section{Efecto de una tormenta de nieve sobre la interacción colibrí-planta: los patrones espacio- temporales se recobran rápido}

\author{
Román Díaz-Valenzuela ${ }^{1,2}$ and Raúl Ortiz-Pulido ${ }^{1,3 凶}$ \\ ${ }^{1}$ Laboratorio de Ecología de Poblaciones, Centro de Investigaciones Biológicas, Universidad Autónoma del Estado de Hidalgo. Apartado postal 69, \\ 42001 Pachuca, Hidalgo, México. \\ ${ }^{2}$ Laboratorio de Vertebrados, Centro Iberoamericano de la Biodiversidad, Universidad de Alicante, 03080 Alicante, España. \\ ${ }^{3}$ Current address: Laboratorio de Ecología de la Conducta, Centro Tlaxcala de Biología de la Conducta, Universidad Autónoma de Tlaxcala-UNAM, \\ Carretera Tlaxcala-Puebla km 1.5, Colonia Xicohtencatl S/N, 90070 Tlaxcala, Tlaxcala, México. \\ \raulortizpulido@yahoo.com
}

\begin{abstract}
The global climatic change could cause, in some places, appearance of meteorological phenomena considered rare. If we understand the effect of these phenomena on birds we can understand how birds respond to weather changes. We report here the effect of a severe snowfall on hummingbird activity, flower abundance and hummingbird-plant interaction in a temperate forest of central Mexico. During our study we registered 1 hummingbird species (Hylocharis leucotis) and 7 plant species (Fuchsia thymifolia, F. microphyla, Salvia amarissima, S. elegants, Cestrum roseum, Penstemon campanulatus and Lonicera mexicana). Before the sudden climatic phenomena we registered 66 records of hummingbirds, 8700 flowers, and 6 hummingbird visits to flowers. During the phenomena, there were zero hummingbird records, 160 flowers and zero visits. A month after the event there were 67 hummingbirds records, 1825 flowers and 13 visits. Hummingbird activity recovered rapidly after the snowstorm, but 6 of 7 plants species lost all their flowers, except for L. mexicana, which received all hummingbird visits a month after the climatic event.
\end{abstract}

Key words: bird pollinated flowers, global climate change, hummingbirds, ornithophylous plant species, snowstorm effect, sudden changes in the average state of the time.

Resumen. El cambio climático global podría causar fenómenos meteorológicos considerados como raros. Si entendemos
el efecto de estos fenómenos en las aves podríamos comprender como las aves responden a este tipo de cambios en el
tiempo. Aquí documentamos el efecto de una nevada severa sobre la actividad de colibríes, la abundancia floral y la
interación colibrí-planta en un bosque templado del centro de México. Durante nuestro estudio registramos 1 especie de
colibrí (Hylocharis leucotis) y 7 especies de plantas (Fuchsia thymifolia, F. microphyla, Salvia amarissima, S. elegants,
Cestrum roseum, Penstemon campanulatus y Lonicera mexicana). Antes de la nevada registramos 66 avistamientos
de colibríes, 8700 flores y 6 visitas de colibríes a las flores. Durante el fenómeno hubo cero registros de colibríes, 160
flores y cero visitas. Un mes después del evento climático hubo 67 registros de colibríes, 1825 flores y 13 visitas. La
actividad de los colibríes se recuperó rápido después de la nevada, pero 6 de 7 especies de plantas perdieron todas sus
flores, exceptuando a L. mexicana, que recibió todas las visitas de colibríes 1 mes después del evento climático inusual.

Palabras clave: flores polinizadas por colibríes, cambio climático global, colibríes, plantas ornitofílicas, efecto de nevada, cambios repentinos en el estado del tiempo.

\section{Introduction}

The Earth's climatic system is changing (Peterson et al., 2002; Watkinson et al., 2004). The evidence suggests that it could be a global climatic change (Ordano, 2003; Watkinson et al., 2004), and among the consequences are sudden changes in the average state of the weather

Recibido: 25 octubre 2010; aceptado: 02 marzo 2011
(SuCAST) which in turn will cause apparition of meteorological phenomena considered rare in some places. Among these SuCAST will be droughts, low temperatures, hurricanes and severe snowstorms (e.g., Watkinson and Gill, 2002; Watkinson et al., 2004). The effect of these phenomena on the fauna could be long or short term. A drought, for example, can affect a locality for months or years, while a hurricane or a severe snowstorm can have immediate catastrophic effects (Rotenberry et al., 1993). 
There is evidence that birds are sensitive to SuCAST (e.g., Kalela, 1949; Knopf and Sedgwick, 1987; DeSante et al., 1993; Peterson et al., 2001; Tejeda-Cruz and Sutherland, 2005). However, SuCAST has been only hypothetically related to fauna (e.g., Wagner, 1946; Inouye et al., 1991; Gass et al., 1999). SuCAST, depending on their intensity, duration and affected area, can influence in different ways avian populations (e.g., Pickett and White, 1985; Rotenberry et al., 1993).

The hummingbird-plant interaction is an excellent model to understand how SuCAST influence birds, both directly, through mortality due to changes in temperature, and indirectly, through loss of food sources. Both SuCAST effects has been hypothesized, but never tested in field (Wagner, 1946; Inouye et al., 1991; Gass et al., 1999). The hummingbird-plant interaction could be affected by such events since the abundance and distribution of hummingbirds dependent on the flower / nectar availability in the environment (Stiles, 1977, 1978; Ortiz-Pulido and Díaz, 2001; Ortiz-Pulido and Vargas-Licona, 2008) and SuCAST affects such flower availability (Wagner, 1946; Gass et al., 1999).

Hummingbirds pollinate close to $15 \%$ of angiosperm plants in many vegetation types in America (Buzato et al., 2000). Therefore, a SuCAST influencing hummingbirds will affect the reproductive success of the plants visited by them, and in turn will affect other animals that depend on flowers and fruits.

Here we report how a SuCAST affected the activity of a hummingbird species, the abundance of flowers visited by this species and the interaction between these in a temperate forest located in central Mexico. We present data on hummingbird activity, flower abundance, and interaction between both groups, before, during, an after the SuCAST.

\section{Materials and methods}

This study was conducted in the El Chico National Park located near Pachuca City, Hidalgo, Mexico (98 $42^{\circ} 33^{\prime \prime} \mathrm{W}, 20^{\circ} 11^{\prime} 22^{\prime \prime} \mathrm{N}, 2$ 900-3 $080 \mathrm{~m}$ a.s.1.). The climate is semi-cold subhumid with summer rains (COEDE-UAEH, 2004), with a mean annual precipitation of $1030 \mathrm{~mm}$, mean annual temperature of $14.3^{\circ} \mathrm{C}$, and mean temperature of the coldest month of $12.1^{\circ} \mathrm{C}$ (National Water Commission, unpublished data). The place is dominated by a dense temperate forest, with a 20-40 m canopy, and 2 lower vegetation strata: a scarce herbaceous, and a shrub cover (Calderón and Rzedowski, 2001). In the El Chico National Park there are reports of 7 hummingbird species and at least 20 plant species whose flowers are visited by them (Villada, 1873; Arregui, 2004;
Mauricio, 2005; Martínez-García, 2006; Díaz-Valenzuela, 2008; Ortiz-Pulido and Vargas-Licona, 2008; Ortiz-Pulido et al., 2008).

On January 1, 2008, there was an intense snowstorm, accompanied by wind and rain (Mota-López, 2008). It left an accumulated snow layer of approximately $20 \mathrm{~cm}$ deep. The temperature varied between $-6^{\circ}$ and $3^{\circ} \mathrm{C}$ during 3 days. This type of phenomena is uncommon in the place. During the last 50 years it has been reported only 3 times (1978, 1997, and 2008); however for the first 2 events there is no technical information about their magnitude (Sergio Alarcón Martínez, National Water Commission Hidalgo, com. pers.). During the 2008 snowstorm, close to $50 \%$ of the trees (Abies religiosa, Pinaceae) lost many of their branches in a surveyed area of 12 ha (RVD, pers. obs.). The snow remained in the area for at least 15 days.

The only hummingbird species recorded during the 2008 SuCAST was the White-eared Hummingbird (Hylocharis leucotis), which is a resident species. At the locality, this species has been recorded foraging throughout the year on flowers of Castilleja tenuiflora, C. moranensis, Penstemon barbatus, P. roseus, P. campanulatus (Fam. Scrophulariaceae), Fuchsia thymifolia, F. microphylla (Onagraceae); Macromeria pringlei (Boraginaceae), Salvia elegans, S. amarissima, Stachys coccínea, Stachys sp., Scutellaria caerulea, Prunella vulgaris (Labiateae), Solanum nigrescens, Cestrum roseum (Solanaceae), Lonicera mexicana (Caprifoliacea), Tillansdia violacea, T. erubescens (Bromeliaceae) and Senecio angulifolius (Compositae) (Arregui, 2004; Díaz-Valenzuela, 2008; Ortiz-Pulido et al., 2008).

Our fieldwork was carried out before, during, an after the SuCAST, from December 2007 to February 2008. We established a $350 \times 350 \mathrm{~m}$ plot (i.e. 12 ha) on the north face of a hill. The area was divided into 49 subplots of $50 \times 50 \mathrm{~m}$. We registered all visual and acoustical hummingbird records (from here, hummingbird activity), and introductions of hummingbird bills into flowers (from here, hummingbird visits) in a $25 \mathrm{~m}$ radius from the center of every subplot. Every subplot was surveyed from 07:00 to $12: 00 \mathrm{~h}$ during 10 minutes every month, registering hour, hummingbird species, and hummingbird activity. Each subplot was visited 1 time during the SuCAST. To determine the avian species we used hummingbird field guides (Williamson, 2001; Howell, 2002; Ortiz-Pulido et al., 2006). To determine flower abundance we registered the number of flowers in 4 areas of $9 \times 9$ m (i.e. $324 \mathrm{~m}^{2}$ ) in every subplot. The 4 values were averaged to obtain flower abundance per subplot. This technique has proved to indicate a reliable measure for flower abundance in subplots of 50 x 50 m (Díaz-Valenzuela, 2008; Ortiz-Pulido and Vargas-Licona, 2008). We only took into account open 
and mature flowers from those plant species whose flowers were visited by hummingbirds during the study period. Plant species identity was determined using a reference collection located in the Herbarium of the Universidad Autonoma del Estado de Hidalgo.

The month long relationship between hummingbird activity and flower abundance, previous, during, and after the SuCAST, was tested using a Spearman correlation test. Monthly relationships were obtained taking into account 49 samples, 1 for each subplot. Spatial autocorrelation in the response variable was tested using the Mantel test provided by the XLstat program (Addinsoft, 2007), and when spatial dependence was found, we used the Spearman correlation test modified by Dutilleul (1993). This test changes the degree of freedom (using decimal places) to achieve the best interpretation of the statistical significance of spatially explicit data (Dutilleul, 1993; Legendre et al., 2002; Rangel et al., 2006).

\section{Results}

A month before and after the $2008 \mathrm{SuCAST}$, we recorded 1 hummingbird species (White-eared Hummingbird), but none during the phenomena (the 15 days with snow on the ground). We recorded 66 hummingbird sightings before the SuCAST, zero during the climatic phenomena, and 67 afterward, for a total of 133 hummingbird sightings. From this total we were unable to identify the hummingbird species in 17 instances.

Before, during, and after the SuCAST the richness of flourishing plant species varied (Table 1), as well as the number of open-mature flowers. Before SuCAST we recorded 8700 flowers, 160 during the phenomena, and 1825 afterward. During SuCAST all the herbaceous flowers disappeared, except for L. mexicana that displayed 160 flowers (Table 1). Apparently, the SuCAST event determined the disappearance of $\sim 98 \%$ of the flowers.

We recorded 6 hummingbird visits to flowers (4 to F. microphylla, 1 to $S$. elegant and 1 to $S$. amarissima) before SuCAST, zero during the phenomena and 13 visits (all to L. mexicana) afterward. Before and after SuCAST there were significant correlations (Fig. 1) between hummingbird activity and flower abundance (in December $r_{\mathrm{s}}=0.56$, d.f. $=45.70, \mathrm{~F}=21.12, p=0.00003$; in February $\mathrm{r}_{\mathrm{s}}=$ 0.40 , df. $=51.5, \mathrm{~F}=9.70, p=0.00301)$. During the SuCAST we did not apply a correlation test, because there was no hummingbird activity in the 49 subplots.

\section{Discussion}

The 2008 SuCAST event was related to low levels of hummingbird activity in the El Chico National Park. This effect was most likely caused by hummingbirds dying due to the freezing conditions, and indirectly by a reduction of hummingbird food sources, that forced hummingbirds to enter into torpor, or move to other locations. Before and after the 2008 SuCAST there was a significant correlation between hummingbird activity and flower abundance. This relationship has been reported in other studies without a SuCAST context (Wagner, 1946; Wolf, 1970; Feinsinger,

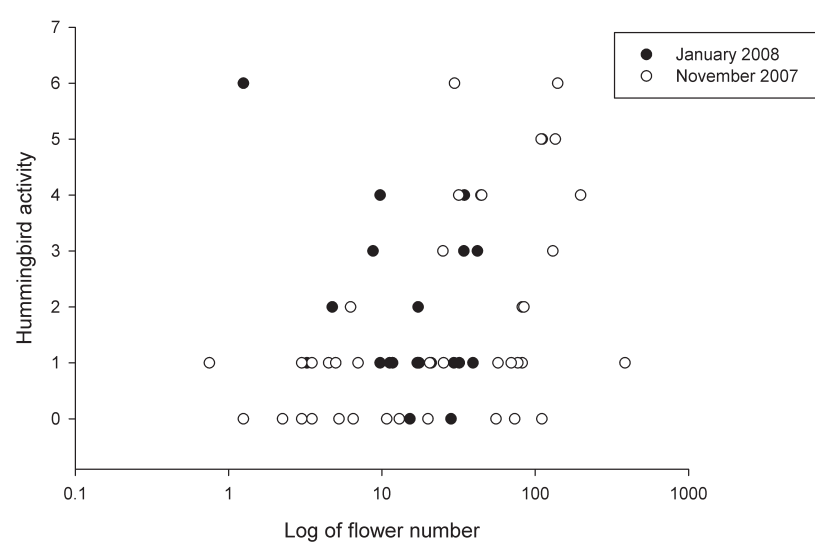

Figure 1. Correlations between flower number and hummingbird activity before (November 2007) and after (January 2008) a sudden change in the average state of the weather at El Chico National Park, Hidalgo, Mexico. Points represent sampling subplots of $50 \times 50 \mathrm{~m}$.

Table 1. Plant species and number of flowers by each one registered before, during and after a snowstorm in a temperate forest of central Mexico in January 1th 2008

\begin{tabular}{|c|c|c|c|c|c|}
\hline Family & Species & December & January & February & TOTAL \\
\hline \multirow[t]{2}{*}{ Onagraceae } & Fuchsia thymifolia & 1315 & 0 & 0 & 1315 \\
\hline & Fuchsia microphylla & 6111 & 0 & 0 & 6111 \\
\hline \multirow[t]{2}{*}{ Labiatae } & Salvia amarissima & 82 & 0 & 0 & 82 \\
\hline & Salvia elegans & 1046 & 0 & 0 & 1046 \\
\hline Solanaceae & Cestrum roseum & 0 & 0 & 13 & 13 \\
\hline Scrophulariaceae & Penstemon campanulatus & 103 & 0 & 0 & 103 \\
\hline Caprifoliacea & Lonicera mexicana & 43 & 160 & 1812 & 2015 \\
\hline
\end{tabular}


1976; Stiles, 1977, 1978; Feinsinger and Colwell, 1978; Baltosser, 1989; Inouye et al., 1991; Gutiérrez and Rojas, 2001; Ortiz-Pulido and Díaz, 2001; Lara, 2006; DíazValenzuela, 2008; Ortiz-Pulido and Vargas-Licona, 2008). Exactly how the hummingbirds responded to the phenomena we could not reliably determine. They could have suffered an increase in mortality (as suggested by Wagner, 1946; Inouye et al., 1991), made altitudinal movements to search for food (as suggested by Ornelas and Arizmendi, 1995), or employ torpor (as suggested by Bench et al., 1997). We did not record dead hummingbirds in the sampled 12 ha during the SuCAST (but we recorded 4 dead bats in the snow), did not find any evidence of altitudinal movements or detect torpor for the hummingbirds. At nearby sites of El Chico National Park at lower altitudes (approx 2 350-2 $900 \mathrm{~m}$ a. s. 1, with 3 different kinds of vegetation: xerophic shrub, Juniperus forest and oak forest) we did not register unusual variation in hummingbird relative abundance. In the lower elevation sites we conducted the same fieldwork effort reported here, and the SuCAST effects were not so severe, with hummingbird activity and flower abundance being similar to other years.

Even though the 2008 SuCAST had an immediate drastic effect on the number of hummingbird sightings, the effect remained short-term. A month after the SuCAST hummingbird activity returned to the same levels (66 previous vs. 67 after). However, the effect on the plants was more destructive. Only 1 of 7 plant species (L. mexicana) displayed flowers after the climatic phenomenon. Therefore the SuCAST was costly in reproductive terms for the majority of the local plant species. Nevertheless, L. mexicana may have benefited from the SuCAST event. It attained all the hummingbird visits after the SuCAST and perhaps profited from an increase in pollen transference. However this was not tested. All our data indicate that the plant-hummingbird interaction system underwent a rapid recovery and that $L$. mexicana was a main element providing nectar sources to hummingbirds a month after the SuCAST.

The rapid recovery detected of the plant-hummingbird interaction could be explained by the high temporal and spatial variability of the hummingbird-plant interaction systems (Díaz-Valenzuela, 2008; Ortiz-Pulido y VargasLicona, 2008). In nature the flower abundance varies and is an aggregated source in time and space, usually located in isolated patches with high local abundance (e.g. Baltosser, 1989; Fleming, 1992; Díaz-Valenzuela, 2008; Ortiz-Pulido y Vargas-Licona, 2008). At our study site, without the occurrence of SuCAST, it has been detected that the flower abundance in $50 \times 50 \mathrm{~m}$ patches can change from thousands to zero within 4 days (Ortiz-Pulido and Vargas-Licona, 2008). From a local perspective, i.e., $50 \times 50 \mathrm{~m}$, it is possible that the change in floral density originated by the 2008 SuCAST is very similar to the variation which occurs naturally in our study site. However, from a landscape perspective, i.e., 12 ha or more, the 2008 SuCAST imposed a serious energetic challenge to hummingbirds, since the flowers of many plant species disappeared from the landscape.

In the 2008 SuCAST event, we detected that flower availability was reduced significantly in the landscape and this was related to hummingbird activity. During normal conditions, the landscape of El Chico National Park shows $\sim 5.68 \mathrm{Kj} /$ ha in floral nectar (Ortiz-Pulido and Lara, unpub. data), and a White-eared Hummingbird individual $(\sim 3.5$ g) needs $\sim 27 \mathrm{kj} /$ day to survive (based on Baltoser, 1989, and Montgomerie y Gass, 1981, estimates). In a SuCAST event, when $\sim 98 \%$ of the flowers disappear, the available nectar energy is reduced at the landscape level. In such conditions hummingbirds either die or deal with the stressful conditions, by moving away or using torpor (as suggested by Wagner, 1946; Inouye et al., 1991; Ornelas and Arizmendi, 1995; Bench et al., 1997). The consequences at the community level are different in each case. If hummingbirds die, some community dynamics could be disrupted or will be decreased for some time. Among the disrupted community dynamics are the hummingbirdplant interactions and the seed production of hummingbird pollinated plant species. If the hummingbirds died, we hypothesized that the interactions would be re-established slowly after the SuCAST, since hummingbird species must explore and colonize the site again. Community dynamics re-start would depend, in this case, upon the response of the hummingbirds to the SuCAST. On the other hand, if hummingbirds flew away or used torpor, we hypothesized that the interaction could be re-started swiftly after the SuCAST, as individual hummingbirds would only need to return to the site and continue with their normal activities when the flowers reappear. However, there is evidence that suggests that a bird species can survive only few hours in torpor state (Bicudo et al., 2002), so torpor may only be a temporal answer for hummingbirds to SuCAST events. If hummingbirds fly away or use torpor, community dynamics re-start depends on the reaction of the plants to the SuCAST, because hummingbirds are still present in the landscape.

When a SuCAST occurs, surely some hummingbirds die, others fly away and others may endure part of the SuCAST using torpor. Unfortunately, the hummingbird primary reaction to SuCAST has not been determined yet. This study revealed evidence that indicates that hummingbird activity was reduced during a SuCAST event, but the causes remain yet unknown. 


\section{Acknowledgments}

We thank the El Chico National Park Direction for permissions and their logistical support in field, Nadja Weisshaupt for the English translation and 2 anonymous reviewers, whose kind suggestions helped us to improve an early version of this paper. Financial support was given by the Programa de Mejoramiento del Profesorado (Secretaria de Educación Pública - México), Consejo Nacional de Ciencia y Tecnología (doctoral scholarship to RDV and sabbatical scholarship to ROP) and the Consejo de Ciencia y Tecnología-Hidalgo (project Diversidad Biológica del Estado de Hidalgo, segunda fase, Fomix-CONACyT-2008-95828).

\section{Literature cited}

Addinsoft, 2007, Program XLstat v. 2007.5. Addinsoft. Barcelona, España.

Arregui, A. L. 2004. ¿A qué nivel de la escala espacial seleccionan los colibríes su área de forrajeo? Tesis de maestría, Universidad Autónoma de Madrid. Madrid, España. 27 p.

Baltosser, W. H. 1989. Nectar availability and habitat selection by hummingbirds in Guadalupe Canyon. Wilson Bulletin 101:559-578.

Bech, C., A. Abe, J. F. Steffensen, M. Berger and J.E.P.W. Bicudo. 1997. Torpor in three species of brazilian hummingbirds under semi-natural conditions. The Condor 99:780-788.

Bicudo, J. E. P. W., A. C. Bianco and C. R. Vianna. 2002. Adaptive thermogenesis in hummingbirds. The Journal of Experimental Biology 205:2267-2273.

Buzato, S., M. Sazima and I. Sazima. 2000. Hummingbirdpollinated floras at three Atlantic forest sites. Biotropica 32:824-841.

Calderón, G. and J. Rzedowski. 2001. Flora fanerogámica del Valle de México. Instituto de ecología A C., CONABIO, Xalapa, Veracruz, México. 1406 p.

COEDE-UAEH (Consejo Estatal de Ecología y Universidad Autónoma del Estado de Hidalgo). 2004. Ordenamiento Ecológico Territorial del Valle Pachuca-Tizayuca. Consejo Estatal de Ecología-Hidalgo, Universidad Autónoma del Estado de Hidalgo. Diario oficial del Estado de Hidalgo. Pachuca, Hidalgo. México. Mayo 2004. 468 p.

DeSante, D. F., O. E. Williams and K. M. Burton. 1993. The monitoring avian productivity and survivorship (MAPS) program: overview and progress. In Status and management of neotropical migratory birds, D. M. Finch and P. W. Stangel (eds.). U.S. Dept. of Agriculture, Forest Service. Fort Collins, Colorado. p. 208-222.

Díaz-Valenzuela, R. 2008. Análisis descriptivo del sistema colibrí- planta, en tres niveles de las escalas espacial, temporal y en la jerarquía ecológica en un paisaje mexicano. Tesis maestría, Universidad de Alicante-CIBIO. Alicante,
España. 59 p.

Dutilleul, P. 1993. Modifying the t-test for assessing the correlation between two spatial processes. Biometrics 49:305-314.

Feinsinger, P. 1976. Organization of a tropical guild of nectarivorous birds. Ecological Monographs 46:257-291.

Feinsinger, P. and R. K. Colwell. 1978. Community organization among neotropical néctar feeding birds. American Zoologist 18:779-795.

Fleming, T. H. 1992. How do fruit- and nectar- feeding birds and mammals track their food resources? In Effects of resource distribution on animal-plant interactions, M. D. Hunter, T. Ohgushi and P. W. Price (eds.). Academic Press, San Diego, California. p. 355-391.

Gass, C. L., M. T. Romich and R. K. Suarez. 1999. Energetics of hummingbirds foraging at low ambient temperature. Canadian Journal of Zoology 77:314-320.

Gutiérrez, A. and S. Rojas. 2001. Dinámica anual de la interacción colibrí-flor en ecosistemas altoandinos del volcán Galeras, sur de Colombia. Tesis de grado, Universidad Nacional de Colombia. Bogotá, Colombia. 125 p.

Howell, S. N. G. 2002. Hummingbirds of North America. The photographic guide. Princeton University Press. Princeton. 219 p.

Inouye, D. W., W. A. Calder and N. M. Waser. 1991. The effect of floral abundance on feeder censuses of hummingbird populations. Condor 93:279-285.

Kalela, O. 1949. Changes in geographic ranges in the avifauna of northern and central Europe in relation to recent changes in climate. Bird-Banding 20:77-103.

Knopf, F. L. and J. A. Sedgwick. 1987. Latent population responses of summer birds to a catastrophic climatological event. Condor 89:869-873.

Lara, C. 2006. Temporal dynamics of flower use by hummingbirds in a highland temperate forest in Mexico. Ecoscience 13:2329.

Legendre, P., M. R. T. Dale, M. J. Fortin, J. Gurevitch, M. Hohn and D. Myers. 2002. The consequences of spatial structure for the design and analysis of ecological field surveys. Ecography 25:601-615.

Martínez-García, V. 2006. Interacciones Colibrí-Planta en tres tipos de vegetación de la reserva de la biosfera Barranca de Metztitlan, Hidalgo, México. Tesis, Universidad Autónoma del Estado de Hidalgo. Pachuca, Hidalgo. México. 57 p.

Mauricio, E. 2005. Interacción colibrí-planta: variación espacial en un matorral xerófilo de Hidalgo, México. Tesis de licenciatura. Universidad Autónoma del Estado de Hidalgo. Pachuca, Hidalgo, México. 58 p.

Montgomerie, R. D. and C. L. Gass. 1981. Energy limitations of hummingbird populations in tropical and temperate communities. Oecologia 50:162-165.

Mota-López, D. [online] 2008. Cubre nieve al menos siete 
municipios de Hidalgo. <http://www.eluniversal.com.mx/ notas/471512.html> El Universal Newspaper. Pachuca, Hidalgo, México. 2 January 2008.

Ordano, M. 2003. Cambio climático y efectos sinérgicos. In Conservación de aves, Experiencias en México, H. Gómez de Silva and A. Oliveras-de Ita (eds.). CIPAMEX. México D.F. p. 214-216.

Ornelas, J. F. and M. C. Arizmendi. 1995. Altitudinal migration: implications for conservation of avian Neotropical migrants in Western Mexico. In Conservation of Neotropical Migratory Birds in Mexico, M. H. Wilson and S. A. Sader (eds.). Maine Agricultural and Forest Experiment Station. Orono, ME. p. 98-112.

Ortiz-Pulido, R. and R. Díaz. 2001. Distribución y densidad de colibríes en la zona baja del centro de Veracruz, México. Ornitología Neotropical 12:297-317.

Ortiz-Pulido, R. and G. Vargas-Licona. 2008. Explorando la relación entre registros de colibríes y abundancia de flores con escalamiento espacio-temporal. Ornitologia Neotropical 19:473-483.

Ortiz-Pulido, R., V. Martínez-García and J. Bravo-Cadena. 2006. Colibríes, Reserva de la Biosfera Barranca de Metztitlán. Universidad Autónoma del Estado de Hidalgo y Dirección de la Reserva de la Biosfera Barranca de Metztitlán. Pachuca, Hidalgo, México. 20 p.

Ortiz-Pulido, R., E. Mauricio-López, V. Martínez-Garcpia, V. and J. Bravo-Cadena. 2008. ¿Sabes quien vive en el Parque Nacional El Chico? Colibríes. Universidad Autónoma de Estado de Hidalgo, Secretaria de Educación Pública-Hidalgo, Dirección del Parque Nacional El Chico. Pachuca, Hidalgo, México. $26 \mathrm{p}$.

Peterson, A. T., V. Sánchez-Cordero, J. Soberón, J. Bartley, R. W. Buddemeier and A. G. Navarro-Sigüenza. 2001. Effects of global climate change on geographic distributions of Mexican Cracidae. Ecological Modelling 144:21-30.

Peterson, A. T., M. A. Ortega-Huerta, J. Bartley, V. SánchezCordero, J. Soberón, R. H. Buddemeier and D. R. B. Stockwell. 2002. Future projections for Mexican faunas under global climate change scenarios. Nature 416:626-629.

Pickett, S. T. A. and P. S. White (eds.). 1985. The ecology of natural disturbance and patch dynamics. Academic Press. New York. $472 \mathrm{p}$.

Rangel, T. F. L. V. B., J. A. F. Diniz-Filho and L. M. Bini. 2006. Towards an integrated computational tool for spatial analysis in macroecology and biogeography. Global Ecology and Biogeography 15:321-327.

Rotenberry, J. T., R. J. Cooper, J. M. Wunderle and G. K. Smith. 1993. Incorporating effects of natural disturbances in managed ecosystems. In Status and management of Neotropical migratory birds, D. M. Finch and P. W. Stangel (eds.). U.S. Dept. of Agriculture, Forest Service. Fort Collins, Colorado. p. 103-108.

Stiles, F. G. 1977. Coadapted competitors: the flowering season of hummingbird-pollinated plants in a tropical forest. Science 198:1177-1178.

Stiles, F. G. 1978. Temporal organization of flowering among the hummingbirds food plants of a tropical wet forest. Biotropica 10:194-210.

Tejeda-Cruz, C. and W. J. Sutherland. 2005. Bird responses to shade coffee production. Animal Conservation 7:169-179.

Tejeda-Cruz, C. and W.J. Sutherland. 2005. Cloud forest bird responses to unusually severe storm damage. Biotropica 37:88-95.

Villada, M. M. 1873. Troquilidos del Valle de México, su descripción y sinonimia adoptada por el profesor John Gould, con algunas notas sobre sus costumbres. Naturaleza 2:339-369.

Wagner, H. O. 1946. Food and feeding habits of Mexican Hummingbirds. Wilson Bulletin 58:69-132.

Watkinson, A. R. and J. A. Gill. 2002. Climate change and dispersal. In Dispersal, J. M. Bullock (ed.). Blackwell Science. Oxford. p. 410-428.

Watkinson, A. R., J. A. Gill and M. Hulme. 2004. Flying in the face of climate change: a review of climate change, past, present and future. Ibis 146:S4-S10.

Williamson, S. L. 2001. A Field Guide to Hummingbirds of North America. Peterson Field Guide Series. Houghton Mifflin. Boston. 263 p.

Wolf, L. 1970. The impact of seasonal flowering on the biology of some tropical hummingbirds. Condor 72:1-14. 